\title{
Female education in post-reform Russia as a social lift
}

\author{
Yulia Viktorovna Bodrova ${ }^{1}$, Aleksey Viktorovich Vinnik, Olga Konstantinovna Ermishkina, \\ Elena Alekseevna Makarova, and Angelina Valerievna Tsyganova
}

Tver State University, Department of Social and Cultural Service, Tver, Russia

\begin{abstract}
A significant expansion of female education for the representatives of different classes was a progressive phenomenon of the "great reforms" of Emperor Alexander II. Against the background of social changes in Russia, women thus received additional opportunities for their socialization and work. The study of the use of female education as a social lift is of interest from the point of view of the history of social modernization. The study aims to study the experience of using female education as a social lift on the example of the Tver province of the Russian Empire. The study uses a set of methods of female and gender history and the local history approach, which collectively make it possible to focus on the regional specifics of the modernization of the female education system in the context of the individual's everyday practices within the framework of an interdisciplinary field. Published statistical data are involved in the research; unpublished documents from the funds of regional archives are also introduced into scientific circulation. The novelty of the article lies in the recreation of the practices of using female education as a social lift in the second half of the $19^{\text {th }}-$ early $20^{\text {th }}$ centuries using the example of the Tver province. Various levels and forms of female education in Russia in the era of "great reforms" and the period that followed them have been studied. The mechanisms of socialization of Russian women of different classes are revealed, depending on the level of education received.
\end{abstract}

Keywords: history of education, teaching methods, educational institutions for the local community

\section{Introduction}

The era of "great reforms" $60 \mathrm{~s}-70 \mathrm{~s}$ of the $19^{\text {th }}$ century provoked radical socio-economic changes in Russian society, one of the manifestations of which was the reassessment of the concept of female upbringing and education $[1,2]$. The public unfolded a wide controversy about the need to introduce a new model of female institutions based on the principles of all-estate, openness, humanistic orientation and public-state partnership [3, 4]. The modernization of female education has led to the development of a network of educational

\footnotetext{
${ }^{1}$ Corresponding author: Bodrova.YV@.tversu.ru
} 
institutions, improving their financial condition by attracting private charitable funds, introducing advanced pedagogical ideas, democratizing the social composition of pupils [5-8]. The availability of education contributed to a gradual change in the social status of women and the formation of new life strategies [9].

\section{$2 \quad$ Materials and methods}

Transformation of the position of women in social stratification is one of the categories of scientific analysis of gender history $[10,11]$. The gender approach allows us to consider the development of female education as an achievement of a progressive society in the struggle for female equality [12]. The study of the regional specifics of modernization processes in the field of education determines the application of the local history methodology [13-16]. Published statistical documents [17] and unpublished materials of the State Archives of the Tver Region were used as a source base for the study.

\section{$3 \quad$ Results}

The post-reform period brought significant social changes to Russian society, during which not only existing class barriers were actively broken down, but also the gender stereotypes. A woman strove for a new social role, as the emancipated person she did not take care of the family and a successful marriage, conversely, she wanted independence, mental and moral improvement. The real way to this was education, equal to that of men.

A key stage in the reform of female education was the approval of the Regulations on Female Schools of the Department of the Ministry of Public Education by Emperor Alexander II in 1858. Similar educational institutions began to be created under the Department of Institutions of the Empress Maria. Due to the support of the public and the attraction of charitable funds, female educational institutions were opened in various regions and differed in their organizational and legal forms, goals, curricula, level of training, and the composition of students.

Tver province was actively involved in the process of reforming the education system. According to the data of the first general census of the population of the Russian Empire in 1897 in terms of literacy of the population, including women, the Tver province occupied one of the first places, which is explained by the proximity to the capital's cultural and educational centers, the presence of qualified and motivated teaching staff, the active position of the provincial government, activities of zemstvo and public organizations. In the province, the number of educational institutions for women, primarily gymnasiums, increased. By the beginning of the 1870s there had been two female gymnasiums in Tver and one in Vyshny Volochyok, moreover, by January 1, 1905 there had been already six female gymnasiums (Bezhetskaya, Vesyegonskaya, Ostashkovskaya, Rzhevskaya, Tverskaya Mariinskaya gymnasium, Tver female gymnasium Rimskaya-Korsakova) [17]. Educational and educational activities in them were organized in accordance with the Regulations on Female Gymnasiums and Gymnasiums of 1870, which emphasized the practical nature of female education, which implied the possibility of applying the abilities of graduates in a wider space than home and family.

Mariinskaya Gymnasium was the first secondary educational institution in the Tver province for girls of all classes and religions. In the post-reform period, the duration of education in the gymnasium increased to 7 years, an $8^{\text {th }}$ pedagogical class was additionally established. Graduates of the $7^{\text {th }}$ grade were issued a certificate that allowed them to work 
as an elementary school teacher, who graduated from the $8^{\text {th }}$ grade - a certificate of a home teacher and a home tutor. The introduction of an additional class opened up broader prospects for graduates for pedagogical activity. The gymnasium was the most numerous in terms of the number of students. In 1906, the total number of female students was 570 [18].

Girls had the opportunity to receive secondary education in private gymnasiums, one of which was A.A. Rimskaya-Korsakova Tverskaya female gymnasium. Girls of all classes and religions were admitted to it, it was supported by tuition fees and funds from the city budget and zemstvo fees.

Since 1905, a secondary specialized educational institution for women, the Tver City Female Commercial School, has been operating in Tver. It had its own charter and consisted of two classes and five departments. The school accepted girls of all classes and religions at the age of 8 , the duration of the study was 7 years. In the first year, 153 people entered the school [19]. Students received general education and the basics of business knowledge. Graduates of the female commercial school had been entitled to enroll in the Pedagogical courses in Tver.

One-year permanent Pedagogical courses for the training of primary school teachers were opened in 1912 in connection with the growing need of the province for school teachers. Those who graduated from secondary educational institutions were admitted to the courses. The first listeners were 40 people, by the beginning of the 1914-1915 academic year their number had reached 78 [20].

It should be noted, that in most cases the daughters of the nobility, clergy and relatively wealthy urban strata studied in gymnasiums and schools. The path to education was much more difficult for the representatives of the lower classes, peasant girls who dreamed of breaking out of poverty and ignorance. It was in Tver that a project was implemented that gave several generations of women a chance for professional self-realization. Tver female teacher's school, founded in 1870 by a prominent zemstvo figure Maksimovich, was a tool for generating and testing many innovations in the organization of an educational institution. First of all, it gave free education to peasant girls, who could not get it anywhere else and in such a volume, since all other secondary educational institutions of Tver were paid. The school teachers tried to equip it with modern teaching aids, new equipment (observatory, laboratory), introduced advanced teaching methods (excursion method, optional classes). Maksimovich believed that students should be taught "smallpox vaccination, familiarize them with the main rules of folk hygiene, practically applicable to rural folk life, with caring for the sick, postpartum women, newborns and, in general, report all medical information available to them by education and applicable to the life of the rural population" [21]. It is no coincidence that the second place in the employment of graduates after teaching activities is occupied by the professions of "paramedic" and "midwife-paramedic", some of the students continued their studies at medical institutes.

The school was distinguished by unique forms of organization of extracurricular activities. Much attention was paid to sports, excursions, aesthetic education, and leisure. Informal, creative traditions in the organization of extracurricular activities have become an example for the pupils in their future life. The school graduated 36-40 female teachers annually; over the 48 years of its existence, it trained 1,200 female teachers [22].

\section{Discussion}

The study of the activities of female educational institutions in individual provinces allows us to conclude that the availability of education was conditional due to the collection of fees from the pupils. Only due to the attraction of charitable funds, a small number of 
representatives of the lower classes received the opportunity of free education. The introduction of advanced pedagogical technologies into the educational process depended on public and private support. Despite the fact that education provided women with the opportunity to change their social status, its relevance began to be felt only by the beginning of the twentieth century.

\section{Conclusion}

Female education in the post-reform period has become a striking social phenomenon. It not only made it possible to solve the problem of training qualified personnel for various social and economic spheres, but also expanded the understanding of the social role of women, allowed her to become a self-sufficient and independent person, provided an opportunity for professional and personal self-realization, and served as a kind of "social lift".

\section{References}

1. I.E. Lyskova, Woman Rus Soc, 3-2, 80-87 (2014)

2. V.Yu. Kapustina, Bul Moscow State Ling Univ. Edu Pedag Sci, 2(766), 77-91 (2016)

3. O.S. Buslaeva, Lecturer 21th, 3, 347-352 (2015)

4. A.V. Spichak, Bylye Gody, 56(2), 652-66 (2020). https://doi.org/10.13187/bg.2020.2.652

5. I.V. Kornilova, T.A. Magsumov, R.R. Shakirov, Europ J Contemp Edu, 16(2), 217-228 (2016). https://doi.org/10.13187/ejced.2016.16.217

6. E.N. Khabaleva, Woman Rus Soc, 3(84), 103-109 (2017).

https://doi.org/10.21064/WinRS.2017.3.9

7. M.Yu. Varavva, Edu Stud, 4, 250-272 (2020).

https://doi.org/10.17323/1814-9545-2020-4-250-272

8. N.A. Sodelnikova, Bul Surgut State Univ, 1(70), 140-150 (2021). https://doi.org/10.26105/SSPU.2021.1.70.016

9. I.V. Kornilova, T.A. Magsurov, Europ J Contemp Edu, 6(2), 352-366 (2017). https://doi.org/10.13187/ejced.2017.2.352

10. M. Makienko, A. Panamaryova, A. Gurban, Procedia - Soc Behav Sci, 166, 18-23 (2015). https://doi.org/10.1016/j.sbspro.2014.12.476

11. R. Pearse, J.N. Hitchcock, H. Keane, Fem Stud Int Forum, 72, 109-126 (2019). https://doi.org/10.1016/j.wsif.2018.05.007

12. N.L. Pushkareva, Woman Rus Soc, 2-3, 32-37 (2002)

13. N.A. Bulygina, V.P. Ermakov, M.S. Bogoslavtseva, Man India, 96(7), 2179-2190 (2016)

14. A. Torre, Hist Crítica, 69, 37-67 (2018). https://doi.org/10.7440/histcrit69.2018.03

15. L.P. Repina, Dial Time, 69, 5-16 (2019)

16. A. Pons, Hispania Nova, 1 Extraord, 52-80 (2020). https://doi.org/10.20318/hn.2020.5366 
17. Uchebnye zavedeniya vedomstva Ministerstva narodnogo prosveshcheniya: Spravochnaya kniga, sostavlennaya po ofitsialnym svedeniyam za 1905 god [Educational institutions of the Department of the Ministry of Public Education: A reference book compiled according to official data for 1905]. (St. Petersburg, 1907)

18. State Archives of the Tver Region. F. 12 - Tver Female Mariinsky Gymnasium, op. 1, c. 157 , let. 11

19. State Archives of the Tver Region. F. 842 - Tver City Female Commercial School, op. 1 , c. 28 , let. 1

20. State Archives of the Tver Region, f. 153 - Permanent Pedagogical Courses of the Tver Provincial Zemstvo, op. 1, c. 114, let. 3

21. A.F. Selivanov, P.P. Maksimovich, osnovatel Tverskoi zhenskoi uchitelskoi shkoly (biograficheskii ocherk s portretom) [P.P. Maksimovich, founder of the Tver women's teacher's school (biographical sketch with a portrait)]. (St. Petersburg, 1901)

22. T.A. Ilyina, Shkola Maksimovicha [Maksimovich's school]. (Tver State University, Tver, 1992) 